\title{
PENGELOLAAN PUSAT SUMBER BELAJAR \\ PADA PUSDIKLAT SDM KESEHATAN \\ DEPARTEMEN KESEHATAN REPUBLIK \\ INDONESIA
}

Oleh: Dewi Sukorini *

\section{Abtsract}

The aim of this research is to explore the possibility for managing Learning Resource Center of Pusdiklat Departmen Kesehatan more effectively. Descriptive analytic method is used in this research. Data Collection are collected through in-depth interview, observation, and document analysis. Those data are then analyzed through several steps such as data reduction, data presentation, conclusion, and verification. Result of this study indicated that the management Learning Resources Center is not adequate to be viewed from theconcept of managementt. The human resources of the center are not adequate in quantity as well as professional quality. The facilities of the center are not adequate to support the intended activities. The lack of budgetary allocation is also hampering the effectiveness of the center operation.

Kata Kunci: pengelolaan, belajar, sumber belajar, pusat sumber belajar, learning resources center

\section{A. PENDAHULUAN}

\section{Latar Belakang}

Salah satu kegiatan yang berperan vital bagi pengembangan dan peningkatan mutu SDM kesehatan adalah pendidikan dan pelatihan. Pendidikan dan pelatihan yang efektif akan menghasilkan SDM kesehatan yang lebih bermutu, sehingga

*) Dewi Sukorini, M.Pd. adalah staf pada Pusat Pendidikan dan Pelatihan Departemen Kesehatan. 
mampu melaksanakan perubahan dan mengikuti perkembangan teknologi yang semakin pesat, yang pada akhirnya berkontribusi pada kinerja SDM secara individu maupun untuk kinerja institusi/organisasi tempat bekerjanya.

Terkait dengan pendidikan dan pelatihan sebagai bagian dari kehidupan masyarakat, teknologi juga merupakan bagian integral dari kehidupan individu dan masyarakat. Dalam realitasnya masih banyak guru, dosen widyaiswara dan pelatih yang menganggap teknologi hanya sekedar alat atau sarana yang dapat membantu mengatasi masalah dalam mengajar atau melatih. Padahal, menuurt Miarso (2004, hal 289-290), teknologi dapat dilibatkan dalam proses yang potensial meningkatkan nilai tambah. Proses tersebut menghasilkan suatu produk, dan untuk itu seringkali diperlukan adanya peralatan atau sarana. Namun karena cepatnya perkembangan IPTEK maka belum semua dapat diikuti oleh institusi Diklat. Hal ini karena keterbatasan sumber dana untuk memenuhi sumber belajar (pengajar, bahan belajar, dan sarana belajar) yang sesuai dengan tuntutan kebutuhan hasil diklat dan perkembangan IPTEK di bidang kesehatan.

Dalam rangka peningkatan efektivitas proses pendidikan dan pelatihan yang didukung dengan sumber belajar yang memadai, maka pada awal tahun 2000 sampai dengan sekarang dikembangkanlah konsep Pusat Sumber Belajar (Learning Resources Centre - LRC) di Pusat Pendidikan dan Pelatihan Kesehatan (Pusdiklat Kesehatan). Salah satu upayanya yang harus ditempuh adalah meningkatkan perannya sebagai Pusat Sumber Belajar (PSB) di bidang kesehatan, dengan tujuan untuk memproduksi alat dan bahan belajar yang mampu memicu motivasi peserta latih dan widyaiswara serta mampu pula meningkatkan keterampilan petugas dalam memberikan pelayanan kesehatan. Visi yang diembannya yaitu: "one stop learning resources services," yaitu tersedianya suatu 
jaringan sumber belajar yang dapat memberikan layanan informasi layanan IPTEK kediklatan dan kesehatan, layanan sarana pelatihan, layanan kepustakaan, layanan nara sumber, layanan pelatihan dan layanan pengembangan organisasi dalam berbagai format.

Dalam mewujudkan Pusat Sumber Belajar yang mudah diakses oleh pembelajar atau yang membutuhkan informasi tentang sumber belajar baik secara individu maupun secara kolektif (organisasional), maka dibuat suatu model pusat sumber belajar yang disusun oleh Pusat Diklat Kesehatan, yaitu suatu model yang berbasis komputer atau elektronik (web site). Pusat Sumber Belajar pada Pusdiklat Kesehatan dikembangkan berdasarkan pemikiran untuk mencapai visi Indonesia Sehat 2010. Hal ini didasarkan pada lima isu penting. Pertama, peningkatan mutu tenaga kesehatan dalam peranannya sebagai pemikir, perencana, dan pelaksana roda pembangunan kesehatan. Kedua, dengan perkembangan IPTEK diberbagai bidang yang berdampak kepada meningkatnya kompleksitas masalah kesehatan. Masalah tersebut baik secara langsung maupun tidak langsung akan mempengaruhi pelayanan kesehatan yang dibutuhkan masyarakat. Untuk itu diperlukan tenaga kesehatan yang handal yang dapat mengikuti perkembangan IPTEK untuk memberi pelayanan kesehatan secara prima. Ketiga, perubahan paradigma di bidang diklat yang berkembang khususnya perubahan orientasi pelatihan, dari trainer oriented menjadi learner oriented, hal ini tentunya menuntut adanya perubahan kebijakan, pola pikir, dan pengembangan program serta pelayanan pelatihan. Keempat, pemberlakuan otonomi daerah yang membawa implikasi terhadap perubahan peran, tanggung jawab, dan kewenangan di tingkat pusat, propinsi, dan kabupaten/kota. Kelima, kebutuhan akan sumber daya manusia kesehatan yang handal dan profesional dibidangnya. 
Pusat sumber belajar yang ada di Pusdiklat Kesehatan saat ini merupakan pusat jaringan pelayanan informasi sumber belajar yang meliputi: sumber daya manusia, yaitu; nara sumber, fasilitator, dan widyaiswara; bahan belajar seperti: kurikulum, modul, texbook, bahan bacaan, literatur/kepustakaan dan metodologi pelatihan (klasikal, diklat jarak jauh, kalakarya); sarana dan prasarana seperti: perpustakaan, ruang belajar, laboratorium, dan peralatan (antara lain: perangkat keras dan perangkat lunak) yang dibutuhkan dalam upaya peningkatan efektivitas dan efisien proses belajar. Sumber belajar yang ada di Pusdiklat Kesehatan tersebut secara fisik sudah ada, namun pada kenyataannya hingga kini belum terdengar keberadaan dan gaungnya sebagai sumber belajar yang dimiliki oleh Pusat Diklat Kesehatan. Oleh karena itu penitng kiranya dilakukan peneltian ilmiah untuk mengungkap pengelolaan Pusat Sumber Belajar pada Pusdiklat Kesehatan.

\section{Pertanyaan Penelitian}

Mengacu pada latar belakang penelitian di atas, maka pertanyaan dalam penelitian ini dirumuskan sebagai berikut:
a. Bagaimana pengelolaan Pusat Sumber Belajar pada Pusdiklat Departemen Kesehatan?
b. Apakah PSB sudah efektiif dalam mencapai tujuan dan fungsinya?
c. Faktor-faktor apa saja yang menghambat pengelolaan PSB pada Pusdiklat Departemen Kesehatan?

\section{Tujuan Penelitian}

Penelitian ini bertujuan untuk:

a. Menggali informasi apa adanya tentang pengelolaan Pusat Sumber Belajar pada Pusdiklat Departemen Kesehatan;

b. Mengidentifikasi efektivitas pencapaian tujuan dan fungsi Pusat Sumber Belajar pada Pusdiklat Departemen Kesehatan; dan

c. Mengidentifikasi faktor-faktor pendukung dan penghambat pengelolaan PSB pada Pusdiklat Departemen Kesehatan. 


\section{Kegunaan Penelitian}

a. Secara teoretis/akademis memberikan informasi tambahan bagi kasanah pustaka pusat sumber belajar sehingga dapat dimanfaatkan oleh mereka yang menaruh perhatian pada studi atau penelitian mengenai PSB.

a. Secara praktis dapat dimanfaatkan oleh pengelola Pusat Sumber Belajar pada Pusdiklat Kesehatan dalam rangka memperbaiki pengelolaan dan efektivitasnya. Selain itu, secara praktis juga memberikan manfaat dalam mendukung program Menteri Kesehatan Republik Indonesia, terutama dalam penyebaran informasi oleh PSB yang ada di Pusdiklat Kesehatan serta upaya meningkatkan kualitas sumber daya manusia untuk tenaga kesehatan di seluruh Indonesia

\section{Acuan Teoretis}

\section{a. Sumber Belajar}

Belajar mengajar sebagai suatu proses merupakan suatu sistem yang tidak terlepas dari beberapa komponen yang saling berinteraksi didalamnya. Salah satu komponen penting dalam proses tersebut adalah sumber belajar. Sumber belajar itu sendiri memiliki berbagai pengertian baik dalam arti sempit maupun dalam arti luas. Namun, definisi apapun yang diberikan, sumber belajar tidak lain adalah suatu daya yang dapat dimanfaatkan untuk kepentingan proses belajar mengajar baik secara langsung maupun tidak langsung, baik sebagian maupun keseluruhan. Oleh karena itu dalam kegiatan belajar mengajar apabila kita dapat mempergunakan sebanyak mungkin macam sumber yang tersedia, maka dapat diasumsikan bahwa semakin banyak variasinya tentu akan semakin baik penangkapan materi pelajaran sesuai dengan tujuan yang ditetapkan.

Banyak ahli memberikan definisi sumber belajar, meskipun pada hakikatnya definisi yang diberikan memiliki kesamaan. Menurut Ely $(1978$, h. 3) menjelaskan bahwa sumber belajar 
adalah data, orang dan atau sesuatu yang memungkinkan seseorang terjadi belajar. Selanjutnya Silber Kenneth (1977, h.8) menjelaskan bahwa sumber belajar meliputi semua sumber yang berkenaan dengan data, manusia, barangbarang yang mungkin dapat digunakan secara terpisah atau kombinasi, yang oleh siswa biasanya digunakan secara optimal untuk memberikan fasilitas dalam kegiatan belajar. Unsur-unsur sumber belajar itu meliputi: pesan, orang, peralatan, metode dan kondisi lingkungan. Siswa diberi kebebasan untuk memilih sumber-sumber belajar yang sesuai dengan minat dan kemampuan masingmasing.

Menurut Percival dan Ellington (1988, h. 124) menjelaskan sumber belajar sebagai satu set bahan atau situasi yang dengan sengaja diciptakan untuk menunjang siswa belajar mandiri. Lebih lanjut Percival dan Ellington memberikan penjelasan bahwa sumber belajar merupakan: "Basically a resources in education or training is a system, set of materials or situation that is deliberately created or set up in order to enable an individual student to learn. To qualify as a true learning resource, the resource must satisfy all of the following three conditions: (a) it must be readily available, (b) it must allow student self pacing and (c) it must be individualized; ie. It must cater for the needs of student working on their own. It there fore follows that a resource must be student centered."

Hal tersebut menjelaskan bahwa sumber belajar yang dipakai dalam pendidikan atau pelatihan adalah suatu sistem yang terdiri dari sekumpulan bahan atau situasi yang diciptakan dengan sengaja dan dibuat agar memungkinkan siswa belajar secara individual. Sumber belajar inilah yang disebut media pendidikan atau media instruksional. Untuk menjamin sumber belajar tersebut cocok untuk belajar harus memenuhi tiga persyaratan sebagai berikut: a) harus 
dapat tersedia dengan cepat, b) harus memungkinkan siswa untuk memacu diri sendiri, c) harus bersifat individual atau harus dapat memenuhi berbagai kebutuhan para siswa dalam belajar mandiri.

Torkleson seperti dikutip oleh Miarso (2000, h. 87), dalam arti luas sumber belajar adalah buku yang melebihi bidang audio visual tradisional dan menjangkau pengembangan bidang teknologi pendidikan masa sekarang dan masa yang akan dating. Mendukung pendapat tersebut, Dale dikutip Sudjana (1989, h. 76) menjelaskan mengenai sumber belajar dalam arti sempit adalah buku atau bahan-bahan tercetak, sedangkan dalam arti luas sumber belajar adalah pengalaman. Sumber belajar dalam pengertian tersebut menjadi sangat luas maknanya seluas hidup itu sendiri. Selanjutnya Dale berpendapat bahwa pengalaman yang dapat memberikan sumber belajar diklasifikasikan menurut jenjang tertentu berbentuk kerucut pengalaman yang disusun dari yang konkrit ke abstrak.

Dari kajian teori di atas dapat disimpulkan bahwa sumber belajar meliputi apa saja dan siapa saja yang memungkinkan siswa dapat belajar. Setiap sumber belajar tidak saja dituntut memuat pesan pembelajaran yang akan disampaikan kepada peserta belajar, namun harus terjadi adanya interaksi secara timbal balik antara peserta belajar dengan sumber belajar tersebut. Sumber belajar dapat juga berarti satu set bahan atau situasi yang sengaja diciptakan untuk menunjang siswa belajar secara individual baik secara langsung, maupun tidak langsung, baik disengaja maupun tidak sengaja.

\section{b. Pusat Sumber Belajar}

Secara historis embrio pusat sumber belajar dapat disimak dari beberapa tahapan. Tahap pertama identik dengan perpustakaan yang hanya terdiri dari media cetak untuk 
penyelenggaraan proses belajar siswa. Tahap kedua, dalam melaksanakan kegiatannya perpustakaan melayani berbagai permintaan yang bervariasi, demikian pula ditunjang dengan pesatnya kemajuan di bidang teknologi dan komunikasi menuntut penyediaan sumber belajar yang variatif yang berupa audio visual, selain media yang sudah ada yaitu media cetak, sehingga muncul istilah Pusat Multi Media. Tahap ketiga, berupa pengakuan akan semakin dibutuhkannya pelayanan dan kegiatan belajar nontradisional, yang membutuhkan ruangan belajar tertentu sesuai dengan kebutuhan, misalnya untuk belajar mandiri dengan modul, simulasi dan permainan. Tahap keempat, yaitu pengembangan sistem instruksional menuntut kegiatan belajar mengajar dengan memberikan penekanan kepada aktivitas si belajar, dimana kegiatan belajar di kelas dan di Pusat Sumber Belajar merupakan suatu rangkaian kegiatan yang terpadu. Dengan demikian Pusat Sumber Belajar lebih luas lagi. Disinilah letak hubungan yang penting antara Pusat Sumber Belajar dengan Pengembangan sistem pembelajaran, segala macam peralatan audio visual segala jenis personal dimaksudkan untuk membantu meningkatkan efektivitas dan efisiensi pembelajaran.

Pusat sumber belajar memiliki ciri-ciri tertentu, yang antara lain: (1) sumber belajar mempunyai daya atau kekuatan yang dapat memberikan sesuatu yang diperlukan dalam proses pengajaran, (2) sumber belajar dapat mengubah tingkah laku yang lebih sempurna sesuai dengan tujuan, (3) sumber belajar dapat dipergunakan secara sendirisendiri, tetapi dapat juga dipergunakan secara kombinasi. Misalnya sumber belajar material dapat dikombinasi dengan devices dan strategi. Sumber belajar modul dapat berdiri sendiri, dan (4) sumber belajar di bagi dua, yaitu sumber belajar yang dirancang sejak awal untuk keperluan belajar; dan sumber belajar yang tinggal pakai yakni sesuatu yang 
pada mulanya tidak dimaksudkan untuk kepentingan belajar, tetapi kemudian dimanfaatkan untuk kepentingan belajar (Soeharto, 1995, h. 56).

Pusat sumber belajar memiliki tujuan umum dan khusus. Tujuan umumnya adalah untuk meningkatkan efektivitas dan efisiensi kegiatan proses belajar mengajar melalui pengembangan sistim instruksional. Hal ini dilaksanakan dengan menyediakan bermacam pilihan untuk menunjang kegiatan kelas tradisional dan mendorong penggunaan cara-cara baru (non tradisional) yang paling tepat dan sesuai untuk mencapai tujuan program akademis. Sedangkan tujuan khususnya meliputi: (1) menyediakan berbagai macam pilihan komunikasi untuk menunjang kegiatan kelas tradisional, (2) mendorong penggunaan cara-cara belajar baru yang paling cocok untuk mencpai tujuan program akademis dan kewajiban instruksional lainnya, (3) memberikan pelayanan dalam perencanaan produksi, operasional dan tindakan lanjutan untuk pengembangan sistim instruksional, (4) melaksanakan latihan untuk para tenaga pengajar mengenai pengembangan sistim instruksional dan integrasi teknologi dalam proses belajar mengajar, (5) memajukan usaha penelitian yang perlu, tentang penggunaan media pendidikan, (6) menyebarkan informasi yang akan memajukan penggunaan berbagai macam sumber belajar yang lebih efektif dan efisien, (7) menyediakan bahan pelayanan produksi bahan pengajaran, (8) memberikan konsultasi untuk modifikasi fasilitas sumber belajar, (9) membantu mengembangkan penggunaan sumber-sumber belajar, dan (10) membantu dalam pemilihan dan pengadaan bahan-bahan media dan peralatannya.

Selain memiliki manfaat dan memiliki tujuan tertentu, pusat sumber belajar juga memiliki fungsi. Menurut Allen and Allen, pusat sumber belajar mempunyai dua fungsi primer, 
yaitu pelayanan dan instruksional. Pelayanan melibatkan ketersediaan material, perlengkapan, bantuan, dan bimbingan yang dibutuhkan oleh pengguna. Fungsi instruksional diimplementasikan melalui bantuan kepada siswa untuk meneliti, mencari, dan menemukan agar pendidikan mereka menjadi realistis. Pengajar harus menyadari ketersediaan kesempatan bagi mahasiswa dan diri mereka sendiri melalui fasilitas yang tergabung. Semakin baik pengetahuan dan pemahaman yang dimiliki mahasiswa dan pengajar, maka mereka akan dapat memanfaatkan dan bergantung pada sumber daya yang ada.

Selain itu, pusat sumber belajar juga memiliki beberapa fungsi yang lain. Pertama, adalah fungsi pengembangan sistem instruksional. Fungsi ini menolong jurusan atau departemen dan staf tenaga pengajar secara individual di dalam membuat rancangan atau disain dan pemilihan option (pilihan) untuk meningkatkan efektifitas dan efisiensi proses belajar mengajar. Hal ini meliputi: (1) Perencanaan kurikulum, (2) Identifikasi pilihan program instruksional, (3) Seleksi peralatan dan bahan, (4) Perkiraan biaya, (5) Penataan tentang pengembangan sistem instruksional bagi staf pengajar, (6) Perencanaan program, dan (7) Prosedur evaluasi.

Kedua, yaitu fungsi informasi. Dalam kehidupan seharihari orang sering memerlukan informasi, baik untuk keperluan pribadi maupun keperluan usahanya. Beberapa macam sumber informasi seperti pusat komputer (Puskom, bahan bacaan, radio, televisi, perorangan, lembaga dsbnya). Jika informasi yang diperlukanhanya sedikit dan yang memerlukannya juga sedikit, maka bahan informasinya dapat disimpan dalam satu file, jika lebih banyak, maka perlu dibentuk perpustakaan lengkap dengan 
katalognya, jika lebih banyak lagi harus menggunakan komputer.

Ketiga, fungsi pelayanan media. Fungsi ini berhubungan dengan pembuatan rencana program media dan pelayanan pendukung yang dibutuhkan oleh staf pengajar dan pelajar, meliputi: sistim penggunaan media untuk kelompok pusat, untuk kelompok kecil, fasilitas dan program belajar sendiri, pelayanan perpustakaan media/bahan pembelajaran, pelayanan pemeliharaan dan penyampaian, pemeberian bahan-bahan dan peralatan.

Keempat, fungsi produksi. Fungsi ini berhubungan dengan penyediaan materi atau bahan instruksional yang tidak dapat diperloleh melalui sumber komersial, hal ini meliputi: penyiapan karya seni asli untuk tujuan instruksional, produksi transparanci untuk OHP, fotography, reproduksi fotography, pemrograman, pengeditan, dan reproduksi rekaman pita suara, pemrograman, pemeliharaan, dan pengembangan sistem televisi di kampus.

Kelima, fungsi administratif. Fungsi ini berhubungan dengan cara-cara bagaimana tujuan dan prioritas dapat tercapai. Fungsi ini berhubungan dengan semua program yang dilaksanakan dan akan melibatkan semua staf dan pemakai dengan cara-cara yang sesuai. Hal ini meliputi beberapa kegiatan.

Dapat dipastikan bahwa kelima fungsi di atas akan selalu dijumpai dalam setiap pusat sumber belajar sebagai suatu lembaga yang berusaha untuk memajukan efektivitas dan efisiensi kegiatan belajar mengajar. Tidak semua pusat sumber belajar berhasil mewujudkan tujuannya atau berfungsi sebagaimana mestinya. Keberhasilan tersebut ditentukan oleh faktor-faktor yang mempengaruhinya. Ada 
sejumlah faktor yang memiliki potensi menentukan efektivitas atau keberhasilan pusat sumber belajar.

Pertama, personel dan sumberdaya administrasi. Administrator pusat sumber belajar yang tidak mempertimbangkan atau tidak menyadari prinsip-prinsip manajemen akan menemukan kesulitan dalam mencapai usaha kooperatif dan terpusat. Individu dalam organisasi harus menyadari kemampuan mereka dalam organisasi dan menjalankan perannya.

Kedua, mengintegrasikan unsur-unsur yang ada ke dalam unit kohesif. Keberhasilan akan tercapai ketika setiap orang menyadari bahwa mereka tidak punya pekerjaan spesifik tetapi mempunyai tanggung jawab, dan selalu mengejar kesempurnaan dalam bekerja. Terkait dengan hal ini, staf pusat sumber belajar dapat dibagi ke dalam dua kategori, yaitu: staf profesional dan sfat pendukung. Staf profesional adalah pekerja yang gelar formal dalam bidang perpustakaan dan audiovisual, memiliki tanggung jawab, memahami tujuan pusat sumber belajar dan akademi, memahami fungsi dan operasi pusat sumber belajar. Sedangkan staf pundukung adalah teknisi dan klerikal. Mereka harus dilatih secara formal terlebih dahulu.

Ketiga, anggaran. Proses anggaran tidak selalu dapat didefinisikan dengan jelas; teknik formulasi dan eksekusi tergantung pada pilihan individual. Keberhasilan pusat sumber belajar bergantung pada ukuran anggaran dan cara pengaturannya. Hal ini tidak otomatis bahwa anggaran harus besar. Persiapan anggaran dan eksekusi yang tepat dapat menciptakan pusat sumber belajar yang sempurna. Bidang yang perlu dipertimbangkan dalam merencanakan anggaran adalah: (1) standar akreditasi yang ada, (2) alokasi anggaran yang tersedia, (3) apakah dalam periode 
establishing atau established, (4) apakah dana dialokasikan berbasis pada tiap departemen, atau berbasis alokasi pembelian pada saat dibutuhkan. Pada umumnya, dana diatur dalam dua cara: (1) diatur langsung oleh direktur dan diberikan pada saat dibutuhkan pembelian, (2) didistribusikan dalam jumlah tetap untuk tiap departemen.

Keempat, pemilihan material dan perlengkapan. Pemilihan material dan perlengkapan untuk pusat sumber belajar adalah unsur vital dalam memenuhi kebutuhan-kebutuhan mahasiswa dan pengajar. Prosedur pemilihan berbasis utama pada kesesuaian dengan tujuan instruksional kampus. Adanya petunjuk yang berisi prosedur umum dan kecenderungan adalah hal yang diperlukan. Petunjuk ini harus diuji secara regular dan dimodifikasi sesuai kebutuhan. Pemilihan material dan perlengkapan mempunyai prioritas lokal dan petunjuk baku tidak dapat begitu saja diterapkan menyeluruh. Faktor-faktor yang memengaruhi institut dalam hal ini adalah kurikulum, anggaran, dan besarnya koleksi. Pada saat menambah koleksi, penekanan harus memperhatikan konsep total material dalam format cetakan dan non-cetakan. Kelayakan dapat diukur berdasarkan pada kombinasi material dalam pola yang terintegrasi dan menyatu. Keberhasilan pusat sumber belajar akan bergantung pada seberapa baik proses seleksi dapat dicapai dalam sepanjang sejarah institusi. Koleksi sempurna tidak muncul secara tiba-tiba. Seleksi material harus dipengaruhi oleh: (1) ukuran institusi, (2) tujuan pendidikan, (3) rentang kurikulum, (4) ukuran koleksi sekarang, (5) kelayakan koleksi, dan (6) dana yang tersedia.

Dari penjelasan di atas dapat dikatakan bahwa pusat sumber belajar merupakan wahana yang memberikan fasilitas atau kemudahan proses belajar manusia, dimana berbagai jenis sumber belajar dikembangkan dan dikelola 
untuk membantu meningkatkan efektivitas dan efisiensi kegiatan pembelajaran.

\section{c. Pengelolaan Pusat Sumber Belajar}

Keberadaan pusat sumber belajar tidak akan berhasil mewujudkan tujuannya apabila tidak dikelola dengan baik. Dengan kata lain, keberadaan pusat sumber belajar memerlukan manajemen yang baik agar dapat memberikan manfaat yang maksimal bagi penggunanya. Hal ini karena pengelolaan (manajemen) merupakan sebuah bentuk pekerjaan yang mencakup pengkoordinasian sumber daya yang ada ke arah pencapaian sasaran organisasi (Rue, at al, (1992), h. 4). Pendapat lain mengatakan pengelolaan proses yang dilakukan oleh satu atau lebih individu untuk mengkoordinasikan aktivitas orang lain untuk mencapai tujuan-tujuan tidak mungkin dapat dicapai oleh tindakan seorang individu (Harsey dan Kenneth, 1988, h. 6). Jika dirujuk pada kedua definisi di atas, maka pengelolaan pada dasarnya merupakan upaya sistematis yang dapat meningkatkan pencapaian tujuan secara tepat dan hemat. Oleh karena itu, pengelolaan terkait dengan fungsi-fungsi manajemen yang menurut Hersey dan Blanchard (1988, h. 6) terdiri atas perencanaan, pengorganisasian, pemotivasian, dan pengendalian.

Sebagaimana telah dijelaskan dalam bagian sebelumnya, bahwa tahap pertama dalam proses menejemen adalah perencanaan. Perencanaan merupakan suatu proses kegiatan untuk menentukan tindakan dan pekerjaan yang akan dilakukan secara terkoordinasi dan terarah dalam pelaksanaan sesuatu tugas dengan memperhatikan pengetahuan dan pengalaman yang lalu dengan keadaan yang dihadapi. Dalam pengelolaan pusat sumber belajar, perencanaan juga perlu dilakukan, dengan menetapkan berbagai sasaran dan rencana kegiatan yang diarahkan untuk pencapaian tujuan. Perencanaan yang perlu 
dilakukan juga mencakup banyak hal, seperti sumber daya manusia, penyediaan fasilitas, keuangan, pemanfaatan dan pemeliharaannya.

Langkah kedua dalam pengelolaan pusat sumber belajar adalah melakukan pengorganisasian. Pengorganisasian adalah pencapaian hubungan-hubungan tingkah laku diantara pegawai-pegawai sedemikian rupa sehingga dapat bekerjasama secara efisien, mencapai tujuan terhadap saran-saran, dan memperoleh kepuasan pribadi dalam melaksanakan tugas-tugas tertentu dan yang diperlukan. Dalam pengelolaan pusat sumber belajar, pengorganisasian juga perlu dilakukan untuk mengorganisir sumber daya yang ada. Pengorganisasian ini dilakukan untuk menciptakan sinergi dan kerjasama untuk mengoptimalkan seluruh sumber daya yang ada di dalam organisasi.

Langkah ketiga dalam pengelolaan pusat sumber belajar adalah pergerakan. Pergerakan aktivitas pokok dalam manajemen yang mendorong dan menjuruskan semua sumber daya manusia agar berkeinginan, bertujuan, serta bergerak untuk mencapai maksud-maksud yang hendak dicapai dan merasa kepentingan serta bersatu padu dengan rencana usaha dari pada organisasinya. Inti dari proses pergerakan ini adalah mendorong semua sumber daya manusia yang ada dalam organisasi untuk melakukan tindakan-tindakan yang dapat memberikan kontribusi bagi pencapaian tujuan organisasi. Pergerakan ini juga erat kaitannya dengan upaya pemberian motivasi kepada pegawai agar lebih giat dalam bekerja.

Langkah terakhir dalam proses pengelolaan adalah evaluasi atau sering disebut juga dengan istilah pengawasan. Evaluasi atau pengawasan ialah suatu proses 
untuk menilai dan mengetahui apakah hasil pelaksanaan pekerjaan yang dilakukan telah sesuai dengan rencana, perintah, tujuan atau kebijaksanaan yang telah ditentukan. Evaluasi tersebut bertujuan antara lain untuk mempertebal rasa tanggung jawab terhadap anggota organisasi dalam pelaksanaan pekerjaan, mendidik para bawahan agar melaksanakan pekerjaannya sesuai dengan prosedur yang telah ditentukan, untuk mencegah terjadinya penyimpangan, dan untuk memperbaiki kesalahan dan penyelewengan agar pelaksanaan pekerjaan tidak mengalami hambatan atau pemborosan-pemborosan.

\section{B. METODOLOGI PENELITIAN}

\section{Tempat dan Waktu Penelitian}

Penelitian ini mengambil latar (kancah) di Pusat Pendidikan dan Latihan Departemen Kesehatan Republik indonesia, yang berlokasi di Jalan Hang Jabat Raya F III Kebayoran Baru Jakarta Selatan. Penelitian lapangan di lokasi tersebut dilakukan pada bulan Desember 2005 sampai dengan Februari 2006.

\section{Metode Penelitian}

Metode yang digunakan dalam penelitian ini adalah metode deskriptif analitis. Hal ini mengingat bahwa penelitian ini bertujuan untuk mendiskripsikan suatu kenyataan yang ada di lapangan tanpa adanya intervensi dari peneliti dengan pendekatan kualitatif. Lingkup penelitian ini dibatasi hanya pada Pusat Sumber Belajar yang ada di Pusdiklat Kesehatan dengan menggunakan paradigma kualitatif dengan pendektanan deskriptif analitik. Menurut Taliziduhu Ndraha seperti dikutip oleh Widodo (2000, h. 15), metode penelitian deskriptif adalah suatu metode yang digunakan untuk menemukan pengetahuan yang seluas-luasnya terhadap objek penelitian pada suatu saat tertentu. Dalam rangka menemukan pengetahuan itu, penelitian deskriptif selain mendeskripsikan berbagai kasus yang sifatnya 
umum tentang berbagai fenomena sosial yang ditemukan, juga harus mendeskripsikan hal-hal yang bertsifat spesifik yang disoroti dari sudut ke "mengapaan" dan "kebagaimanaannya" tentang sesuatu yang terjadi.

\section{Teknik Pengumpulan Data}

Pengumpulan data dilakukan melalui observasi, wawancara dan analisis dokumen. Analisis dokumen dilakukan dengan mengumpulkan data-data yang berkaitan dengan penyelenggaraan yang sudah dilakukan oleh Pusat Sumber Belajar, dan laporan-laporan pelaksanaan yang kemudian dianalisis untuk memperoleh realitas data dalam penelitian ini. Sedangkan observasi dilakukan dalam bentuk kata dan tindakan serta wawancara terhadap pengelola Pusat Sumber Belajar. Sumber data dalam penelitian ini adalah Pimpinan Pusat Sumber Belajar, Pengelola Pusat Sumber Belajar serta responden tertentu yang penting sebagai informasi seperti pengelola perpustakaan

\section{Pemeriksaan Kebasahan Data}

Pemeriksaan keabsahan data dilakukan dengan sejumlah kriteria tertentu, yaitu: derajat kepercayaan (credibility), keteralihan (transferability), kebergantungan (dependability) dan kepastian (confirmability).

\section{TEMUAN PENELITIAN}

\section{Gambaran Pusdiklat Kesehatan}

Pusdiklat Kesehatan memiliki visi sebagai "Pusat Rujukan Metodologi." Pusat rujukan berarti bahwa Pusidklat Kesehatan harus menjadi "Master" dalam hal Metodologi dan teknologi pelatihan serta manajemen pelatihan kesehatan.

Tugas Pusdiklat Kesehatan adalah melaksanakan koordinasi dan pelaksanaan Pendidikan dan latihan kesehatan. Dalam 
rangka pelaksanaan tugas tersebut, maka Pusdiklat Kesehatan menjalankan fungsi sebagai berikut:

a. Penyusunan Program Pendidikan dan Latihan Kesehatan

b. Pemberian Pelayanan pelaksanaan Pendidikan dan Latihan Kesehatan

c. Koordinasi pelaksanaan Pendidikan dan latihan Kesehatan

d. Pengendalian mutu Pendidikan dan Latihan Kesehatan

e. Pelaksanaan Pendidikan dan Latihan Kesehatan berkala nasional dan internasional

f. Evaluasi dan penyusunan laporan pelaksanaan Pendidikan dan Latihan Kesehatan

g. Pelaksanaan urusan tata usaha dan rumah tangga.

Dalam kenyataannya, visi yang dirumuskan belum dapat dicapai dan baru sebagian yang tercapai. Hal itu disebabkan oleh minimnya SDM yang menguasai metodologi dan teknologi diklat dan sarana masih tertinggal bila dibandingkan dengan institusi diklat lain.

Dengan melihat masih adanya beberapa kelemahan tersebut, maka wajar apabila visi Pusdiklat Kesehatan belum berhasil diwujudkan. Menurut Piplips lembaga diklat yang baik setidaknya harus didukuing oleh empat hal pokok, yakni: (1) metode, (2) instruktur, (3) kurikulum, dan (4) fasilitas. Jika ada kekurangan salah satu diantara keempat hal tersebut, maka akan berdampak pada efektivitas lembaga diklat.

\section{Profil Pusat Sumber Belajar Pusdiklat Kesehatan}

Pusat sumber belajar (PSB) pada Pusdiklat Kesehatan merupakan pusat jaringan pelayanan informasi sumber belajar yang meliputi: (1) sumber daya manusia, yaitu: nara sumber, fasilitator, instruktur dan widyaiswara; (2) bahan belajar seperti: kurikulum, modul, buku teks, bahan bacaan, jurnal dan metodologi pelatihan/klasikal in class, DJJ, lokakarya; (3) sarana dan prasarana seperti ruang perpustakaan, ruang 
belajar, laboratorium dan peralatan (antara lain: perangkat keras dan perangkat lunak) yang dibutuhkan dalam upaya peningkatan efektivitas dan efisiensi proses belajar.

Pusat Sumber Belajar Pusdiklat Kesehatan menjalankan empat fungsi utama, yaitu fungsi pengkajian, fungsi produksi, fungsi penyebarluasan, dan fungsi pelayanan. Sudah banyak aktivitas yang dilakukan oleh PSB Pusdiklat kesehatan, seperti: membuat skema model jaringan dan mekanisme antar komponen jaringan, membuat data base sumber belajar, membuat mekanisme akses informasi sumber belajar dengan ijin kepemilikan, membuat mekanisme akses informasi sumber belajar bebas, melaksanakan pelatihan bagi pelatih soft ware SI DIKLAT SDM Kesehatan, melakukan pembinaan dan pengembangan PSB di daerah, semiloka pemberdayaan pengelolaan PSB, pelatihan perpustakaan elektronik, dan monitoring dan evaluasi pengembangan PSB di propinsi.

Apabila melihat fungsi PSB Pusdiklat tersebut, maka relevan dengan fungsi PSB yang dikemukakan oleh Allen and Allen, yang menyatakan bahwa salah satu fungsi PSB adalah pelayanan. Pelayanan melibatkan provisi apakah material, perlengkapan, bantuan, dan bimbingan dibutuhkan oleh pengguna. Karti Soeharto juga berpendapat bahwa fungsi PSB diantaranya adalah fungsi fungsi informasi, fungsi pelayanan media, dan fungsi produksi. Fungsi informasi terkait penyebarluasan informasi kepada pihak-pihak yang membutuhkan, fungsi pelayanan media berhubungan dengan pembuatan rencana program media dan pelayanan pendukung yang dibutuhkan oleh staf pengajar dan pelajar, dan fungsi produksi berhubungan dengan penyediaan materi atau bahan instruksional yang tidak dapat diperloleh melalui sumber komersial. Dengan demikian jelas sekali bahwa profil PSB Pusdiklat Kesehatan fungsinya sesuai dengan teori yang ada. 


\section{Pengelolaan Pusat Sumber Belajar Pusdiklat Kesehatan}

Temuan penelitian, menunjukkan bahwa secara umum pengelolaan Pusat Sumber Belajar di Pusat Pendidikan dan Latihan Kesehatan sudah melaksanakan pola pengelolaan sesuai standar manajemen, yang meliputi perencanaan, pengorganisasian, pelaksanaan dan evaluasi. Namun demikian, secara keseluruhan dalam pelaksanaannya belum memadai, karena tidak didukung secara penuh oleh faktorfaktor pendukungnya.

Apa yang dilakukan oleh Pusat Sumber Belajar di Pusat Pendidikan dan Latihan sudah merujuk pada prinsip pengelolaan yang terdapat dalam literatur-literatur manajemen. Pengelolaan, menurut Stoner yang dikutip Handoko, dapat diartikan sebagai proses perencanaan, pengorganisasian, pengarahan, dan pengawasan usaha-usaha para anggota organisasi dan pengguna sumber daya organisasi lainnya agar mencapai tujuan organisasi yang telah ditetapkan. Pendapat yang sama mengatakan bahwa pengelolaan adalah proses perencanaan, pengorganisasoian, pengarahan dan pengawasan aktivitas sebuah organisasi untuk mencapai sasaran tertentu.

\section{Faktor-faktor yang Mempengaruhi Efektivitas Pengelolaan Pusat Sumber Belajar Pusdiklat Kesehatan}

Temuan penelitian menunjukkan bahwa setidak ada tiga faktor yang mempengaruhi efektivitas pengelolaan Pusat Sumber Belajar. Ketiga faktor tersebut yaitu sumber daya manusia, sarana dan prasarana, dan keuangan. Dari aspek sumber daya manusia diketahui bahwa sumber daya manusia yang ada di PSB belum cukup memadai baik dari segi kualitas maupun kuantitas. Pegawai pada umumnya tidak paham benar tentang PSB, sehingga tidak dapat menyelesaikan pekerjaannya 
dengan baik. Tidak hanya masalah kemampuan, komitmen para pegawai juga masih rendah sehingga kurang serius dalam menyelesaikan pekerjaan. Kurangnya komitmen ini antara lain disebabkan pegawai umumnya terlalu sibuk dengan pekerjaan di tempat lain dan menganggap bekerja di PSB hanya kerja sambilan. Selain masalah kualitas, dari segi kuantitas SDM di PSB juga terjadi masalah. Seperti di perpustakaan, sampai saat ini belum disediakan tenaga fungsional sehingga proses pelayanan masih menggunakan standar lokal.

Aspek sarana dan prasarana di PSB kondisinya juga belum memadai. Seperti fasilitas komputer diketahui masih minim dan sudah tertinggal yang sebenarnya sudah tidak layak pakai. Fasilitas yang dinilai perlu, seperti ruangan khusus aktivitas, house production, dan ruang display, belum tersedia sehingga kegiatan tidak dapat berjalan optimal.

Dari aspek keuangan juga belum memadai. Meskipun sudah ada dana alokasi khusus operasional, namun jumlahnya tidak mencukupi untuk pengadaan fasilitas yang dianggap perlu. Minimnya anggaran ini juga berimplikasi pada kesejahteraan pegawai yang masih dinilai kurang, sehingga mendorong rendahnya komitmen pegawai terhadap organisasinya.

Ketiga faktor yang mempengaruhi efektivitas pengelolaan PSB di Pusdiklat Kesehatan tersebut secara teoritis sesuai dengan pendapat Karti Soeharto yang mengungkapkan bahwa diantaranya ada tiga (3) faktor yang mempengaruhi efektivitas atau keberhasilan pengelolaan pusat sumber belajar, yaitu: (1) personel dan sumberdaya administrasi, (2) anggaran, dan (3) pemilihan material dan perlengkapan.

Dengan demikian pusat sumber belajar yang tidak mempertimbangkan sumber daya manusia akan menemukan kesulitan dalam mencapai usaha kooperatif dan terpusat. 
Individu dalam organisasi harus menyadari kemampuan mereka dalam organisasi dan menjalankan perannya. Terkait dengan masalah anggaran, maka keberhasilan pusat sumber belajar bergantung pada ukuran anggaran dan cara pengaturannya. Hal ini tidak otomatis bahwa anggaran harus besar, tetapi tergantung bagaimana mengelolanya.. Demikian pula dengan masalah fasilitas, maka keberadaan fasilitas dalam pusat sumber belajar merupakan unsur vital dalam memenuhi kebutuhan-kebutuhan mahasiswa dan pengajar. Prosedur pemilihan berbasis utama pada kesesuaian dengan tujuan instruksional PSB.

\section{Kemungkinan untuk Meningkatkan Efektivitas Pengelolaan Pusat Sumber Belajar Pusdiklat Kesehatan}

Kondisi sumber daya manusia, fasilitas dan keuangan yang kurang memadai tersebut menyebabkan tidak tercapainya tujuan PSB. Dengan kata lain keberadaan PSB tidak efektif, karena kinerjanya belum sesuai dengan tujuan yang telah ditetapkan. Keberadaan PSB ternyata belum dimanfaatkan secara optimal dan sosialisasinya juga masih minim sehingga tidak banyak diketahui oleh pihak-pihak yang memerlukan. Padahal, Pusat Sumber Belajar dimaksudkan sebagai wahana yang memberikan fasilitas atau kemudahan proses belajar, dengan menyediakan berbagai jenis sumber belajar yang dikembangkan dan dikelola untuk membantu meningkatkan efektivitas dan efisiensi kegiatan pembelajaran. Pusat Sumber Belajar harus menyediakan segala sumber belajar baik media cetak, maupun media audiovisual, sehingga dapat memudahkan proses belajar.

Keberadaan faktor-faktor organisasi yang kurang memadai jelas akan mempersulit dalam upaya pengembangan organisasi PSB. Faktor-faktor organisasi sumber daya manusia, fasilitas, dan keuangan atau anggaran merupakan faktor yang sangat 
mempengaruhi dalam pengembangan organisasi dan keberadaannya saling mendukung. Dengan demikian dapat pahami mengapa Pusat Sumber Belajar di Pusat Pendidikan dan Pelatihan Kesehatan tidak berhasil merealisasikan tujuannya, yaitu disebabkan oleh kondisi faktor-faktor organisasi yang kurang memadai.

Melihat kondisi yang demikian, maka kemungkinan untuk meningkatkan efektivitas pengelolaan PSB adalah dengan memperbaiki kondisi ketiga faktor tersebut. Khususnya untuk meningkatkan kualitas sumber daya manusia, maka salah satu langkah yang dapat ditempuh adalah dengan mengadakan pendidikan dan palatihan bagi para pegawai. Hal ini perlu ditempuh karena menurut Bruner (dalam Semiawan Conny R., 1999), pendidikan merupakan proses membuka kunci kemampuan (unlocking of a capacity). Pendidikan sebagai usaha sadar untuk menumbuhkembangkan potensi sumber daya manusia, merupakan proses pengubahan sikap dan tata laku seseorang atau kelompok orang dalam usaha mendewasakan manusia melalui upaya pengajaran dan pelatihan. Sementara menurut Suprihanto, pelatihan adalah suatu kegiatan untuk memperbaiki kemampuan seorang karyawan dengan cara meningkatkan pengetahuan dan keterampilan karyawan dalam menjalankan suatu pekerjaan. Hal yang hampir sama dikemukakan oleh Ranupandojo dan Husnan yang mendefinisikan pelatihan sebagai suatu kegiatan untuk memperbaiki kemampuan kerja seseorang dalam kaitannya dengan aktivitas ekonomi. Dengan demikian jelas sekali bahwa pendidikan dan pelatihan merupakan salah satu upaya yang paling efektif untuk meningkatkan pengetahuan dan keterampilan. 


\section{SIMPULAN DAN SARAN}

\section{Simpulan}

Berdasarkan temuan penelitian seperti telah diuraikan di atas, maka kesimpulan penelitian ini adalah:

a. Pusdiklat Kesehatan bertugas melaksanakan koordinasi dan pelaksanaan Pendidikan dan latihan kesehatan. Fungsi yang dijalankannya adalah (1) Penyusunan Program Pendidikan dan Latihan Kesehatan, (2) Pemberian Pelayanan pelaksanaan Pendidikan dan Latihan Kesehatan, (3) Koordinasi pelaksanaan Pendidikan dan latihan Kesehatan, (4) Pengendalian mutu Pendidikan dan Latihan Kesehatan, (5) Pelaksanaan Pendidikan dan Latihan Kesehatan berkala nasional dan internasional, (6) Evaluasi dan penyusunan laporan pelaksanaan Pendidikan dan Latihan Kesehatan, dan Pelaksanaan urusan tata usaha dan rumah tangga.

b. Pusat sumber belajar (PSB) pada Pusdiklat Kesehatan merupakan pusat jaringan pelayanan informasi sumber belajar yang meliputi: (1) sumber daya manusia, (2) bahan belajar, dan (3) sarana dan prasarana. Pusat Sumber Belajar Pusdiklat Kesehatan menjalankan empat fungsi utama, yaitu fungsi pengkajian, fungsi produksi, fungsi penyebarluasan, dan fungsi pelayanan.

c. Pusat Sumber Belajar di Pusat Pendidikan dan Latihan Kesehatan secara umum sudah mererapkan pengelolaan PSB sesuai standar manajemen, yang meliputi perencanaan, pengorganisasian, pelaksanaan dan evaluasi. Namun demikian pelakasanaannya belum memadai. Dukungan sumber daya manusia masih lemah, baik dari segi kualitas maupun kuantitas. Sarana dan prasarana PSB kondisinya juga masih minim, sehingga menjadi kendala dalam kegiatan operasional. Demikian pula dengan aspek keuangan juga belum memadai sehingga kegiatan di dalam organisasi tidak dapat berjalan lancar. 
d. Ada tiga faktor yang mempengaruhi efektivitas pengelolaan Pusat Sumber Belajar, yaitu sumber daya manusia, sarana dan prasarana, dan keuangan. Dari aspek sumber daya manusia diketahui bahwa sumber daya manusia yang ada di PSB belum cukup memadai baik dari segi kualitas maupun kuantitas. Aspek sarana dan prasarana di PSB kondisinya juga belum memadai. Fasilitas yang dinilai perlu, seperti ruangan khusus aktivitas, house production, dan ruang display, belum tersedia sehingga kegiatan tidak dapat berjalan optimal. Dari aspek keuangan juga belum memadai. Meskipun sudah ada dana alokasi khusus operasional, namun jumlahnya tidak mencukupi untuk pengadaan fasilitas yang dianggap perlu.

e. Kemungkinan yang dapat dilakukan untuk meningkatkan efektivitas Pusat Sumber Belajar Pusdiklat Kesehatan adalah dengan mingkatkan kualitas dan kuantitas sumber daya manusia, perbaikan sarana dan prasana PSB, meningkatkan anggaran PSB dan meningkatkan sosialisasi keberadaan PSB beserta produk-produknya.

\section{B. Saran}

Berdasarkan bebarapa kesimpulan sebagaimana tersaji di atas dapat direkomendasikan beberapa hal sebagai berikut:

a. Pengelolaan Pusat Sumber Belajar pada Pusdiklat Kesehatan perlu diperbaiki dan disempurnakan. Upaya perbaikan hendaknya diarahkan kepada semua unsur pendukung PSB, baik sumber daya manusia (SDM), sarana dan prasarana, maupun keuangan. Hal ini memerlukan political will yang serius dari pemegang otoritas Pusdiklat Kesehatan sebagai penanggung jawab penyelenggaraan PSB. Perbaikan SDM serta sarana dan prasarana secara kuantitas maupun kualitas tidak dapat dilakukan tanpa dukungan dana. Dukungan finansial ini jelas menuntut kemauan keras pemagang otoritas Pusdiklat Kesehatan. 
b. Efektivitas Pusat Sumber Belajar pada Pusdiklat Kesehatan perlu ditingkatkan dengan cara lebih mengintensifkan segenap potensi PSB yang ada. Hal ini antara lain dapat dilakukan dengan memperbaiki komitmen dan pemahaman pegawai atas PSB. Selain itu, pegawai PSB juga perlu lebih fokus pada pekerjaannnya, dan tidak menganggap PSB dengan sebelah mata sebagai kegiatan sambilan. Pegawai PSB harus benar-benar fokus pada pekerjaannya seraya meningkatkan komitmen dan pemahamannya atas PSB.

c. Untuk menindaklanjuti hasil penelitian ini ada baiknya dilakukan penelitian lanjutan dengan pendekatan kuantitatif untuk melihat efektivitas PSB terhadap kinerja pegawai yang menggunakan layanannya.

\section{DAFTAR PUSTAKA}

Allen, Kenneth W. and Loren Allen, Organization and Administration of the Learning Resources Center in The Community College, Connecticut: The Shoe String Press, Inc., 1973.

AM, Sardiman, Interaksi dan Motivasi Belajar Mengajar, Jakarta: PT. Raja Grafindo Persada, 1987.

Donnelly, James H., James L. Gibson, dan John M. Ivancevich, Fubdamentals of Management, Homewood: Bussiness Publication, Inc., 1987.

Ely, Donal P., Book of Rearding Instructional Technology Center for Instructional Development, Syracuse University,1978.

Faisal, Sanafiah, Format-format Penelitian Sosial, Jakarta: PT RajaGrafindo Persada, 2003.

Gagne, Robert M., Conditions of Learning, http:www.edu. au/archives/ cp/04d.htm, 2000.

Griffin, Ricky W., Management, New Delhi: A.I.T.B.S.Publisher, 1997. Hamalik, Oemar, Kurikulum dan Pembelajaran, Jakarta: Bumi Aksara, 1995.

Handoko, T. Hani, Manajemen, Yogyakarta: BPFE, 1999.

Hersey, Paul dan Kenneth $\mathrm{H}$. Blancahard, Management of 
Organizational Behavior, New Jersey: Prentice-Hall, 1988.

Jackson, John H. dan Vernon A. Musselman, Bussines, New Jersey: Prentice-Hall, 1987.

Kearsley, Greg and Gerhard Stemberger, Gestalt Theory (Wertheimer), http://www.gwu. edu. -tip/wertheim.html, 2000.

Koswara, Dinamika Informasi dalam Era Global, Bandung: Remadja Rosdakarya, 1998.

Miarso, Yusufhadi, Menyemai Benih Teknologi Pendidikan, Jakarta: Prenada Media, 2004.

Parcival, Fred dan Herry Ellington, Teknologi Pendidikan, Jakarta:PT Erlangga 1988.

Philips, Jack J., Handbook of Training Evaluation and Measurement Methods, Texas: Gulf Publishing Company, 1991.

Prawiradilaga, Dewi S., Modul Wawasan Teknologi Pendidikan, FKIP Univeritas Terbuka, 1999.

Pusdiklat Kesehatan Departemen Kesehatan, Laporan Penyusunan Model PSB, 2000.

R., Semiawan C., Peningkatan Kemampuan Manusia. Jakarta: Grasindo, 1999.

Rakhmat, Jalaluddin, Metode Penelitian Komunikasi, Bandung: Remaja Rosdakarya, 1999.

Rue, Leslie W. dan Lloyd L. Byars, Management: Skills and Aplication, Boston: Richard D. Irwin, Inc., 1992.

Soeharto, Karti et al., Teknologi Pembelajaran, Surabaya: SIC, 1995. Soeprihanto, John, Penilaian Kinerja dan Pengembangan Karyawan, Yogyakarta: BPFE, 1998.

Sudjana, H. D., Metode dan Teknik Pembelajaran Partisipatif, Bandung: Falah Production, 2001.

Sudjana, Nana, Teknologi Pengajaran, Bandung, Sinarbaru, 1989.

Syah, Muhibbin, Psikologi Pendidikan: Suatu Pendekatn Baru, Bandung: PT. Remaja Roesdakarya, 1996.

Widodo, Erna dan Mukhtar, Konstruksi Ke Arah Penelitian Deskriptif, Yogyakarta: Avirouz, 2000.

Yusuf, Pawit M., Pedoman Praktis mencari infromasi, Bandung: PT Remaja Rosdakarya, 1995. 